\title{
Municipal solid waste generation in Kathmandu, Nepal
}

\author{
Mohan B. Dangi ${ }^{a, *}$, Christopher R. Pretz ${ }^{b}$, Michael A. Urynowicz ${ }^{c}$, Kenneth G. Gerow ${ }^{b}$, J.M. Reddy ${ }^{c}$ \\ ${ }^{a}$ Department of Geography, California State University, Fresno, 2555 E San Ramon Avenue, M/S SB 69, Fresno, CA 93740, USA \\ ${ }^{b}$ Department of Statistics, University of Wyoming, 100oE. University Avenue, Laramie, WY 82071, USA \\ ${ }^{\mathrm{c}}$ Department of Civil and Architectural Engineering, University of Wyoming, 1000 E. University Avenue, Laramie, WY 82071, USA
}

\begin{abstract}
:
Waste stream characteristics must be understood to tackle waste management problems in Kathmandu Metropolitan City (KMC), Nepal. Three-stage stratified cluster sampling was used to evaluate solid waste data collected from 336 households in KMC. This information was combined with data collected regarding waste from restaurants, hotels, schools and streets. The study found that $497.3 \mathrm{~g}$ capita $^{-1}$ day $^{-1}$ of solid waste was generated from households and $48.5,113.3$ and $26.1 \mathrm{~kg}$ facility $^{-1}$ day $^{-1}$ of waste was generated from restaurants, hotels and schools, respectively. Street litter measured 69.3 metric tons day ${ }^{-1}$. The average municipal solid waste generation rate was 523.8 metric tons day ${ }^{-1}$ or $0.66 \mathrm{~kg} \mathrm{capita}^{-1}$ day $^{-1}$ as compared to the 320 metric tons day ${ }^{-1}$ reported by the city. The coefficient of correlation between the number of people and the amount of waste produced was 0.94 . Key household waste constituents included $71 \%$ organic wastes, $12 \%$ plastics, $7.5 \%$ paper and paper products, $5 \%$ dirt and construction debris and $1 \%$ hazardous wastes. Although the waste composition varied depending on the source, the composition analysis of waste from restaurants, hotels, schools and streets showed a high percentage of organic wastes. These numbers suggest a greater potential for recovery of organic wastes via composting and there is an opportunity for recycling. Because there is no previous inquiry of this scale in reporting comprehensive municipal solid waste generation in Nepal, this study can be treated as a baseline for other Nepalese municipalities.
\end{abstract}

Keywords:

Municipal solid waste, Solid waste generation, Waste characterization, Waste generation in developing countries, Three-stage cluster sampling, Kathmandu

\section{Introduction}

Kathmandu Metropolitan City (KMC), the capital of Nepal, is the most urbanized city in Nepal. With an area of $50.76 \mathrm{~km}^{2}$ (CBS, 1991 ), KMC has a population of 671,846 people (CBS, 2002). From 1991 to 2001, Nepal's population increased by $2.2 \%$ per annum, while KMC's urban population grew by 7.9\% (CBS, 2002; Pradhan, 2004). Increasing urbanization has intensified environmental pressures including unorganized waste disposal. There is limited information regarding the quantity and generation rates of total municipal solid waste (MSW) in KMC (Dangi, 2009). KMC's reports on waste quantities are incomplete (Dangi et al., 2009). For example, KMC only counts the waste that the municipality collects for disposal and household waste collected by the municipal operation is often misinterpreted as the total MSW generated. The stockpiles of waste seen in courtyards, sidewalks and inner streets;

* Corresponding author. Department of Geography, California State University, Fresno, 2555 E San Ramon Avenue, M/S SB 69, Fresno, CA 93740, United States. Tel.: p1 559278 4857; fax: p1 559278 7268. E-mail addresses: mdangi@csufresno.edu, garbagetalk@gmail.com (M.B. Dangi). along the edges of riverbanks; around demolished structures; on abandoned land and filling rear-facing areas of old structures, government complexes, schools and temples go unrecorded as does the waste from renovated facilities such as concrete, bricks, cement mix and debris from fallen structures and waste from agricultural work and temporary settlements.

Previous studies (Asian Development Bank, 2006; Khanal, 1993; Manandhar, 2005; Nippon Koei Co. Ltd. and Yachiyo Engineering Co. Ltd., 2004) have shown that household solid waste generally makes up a large fraction of MSW. For example, Manandhar (2005) reported that household solid waste was $77 \%$ of the MSW stream in KMC and the Asian Development Bank (2006) found that $>80 \%$ of MSW in KMC comes from households. However, Khanal (1993) found that household waste was only $30 \%$ of the total solid waste in a study of Kathmandu Valley towns, including KMC. Nippon Koei Co. Ltd. and Yachiyo Engineering Co. Ltd. (2004) showed that 54\% of KMC's MSW by mass was from households. While the literature has not shown a general consistency in the ratio of household solid waste to total MSW, it has found that household waste makes up a considerable fraction of the solid waste stream. Also, given the time period these studies were conducted, the methods used, the assumptions made and the statistical limitation in designing 
the studies, only further investigation will determine the accurate numbers for household solid waste generation. The pilot study for this research documented the lack of accurate information in this area (Dangi et al., 2008). The pilot study provided some comparative results of household waste generation in KMC, but this waste stream should be examined concomitantly with other sources of MSW. The basis of the methodology used in this research is cluster sampling of strata, identified as a useful, statistically sound tool for estimating household waste generation at the source by Dangi et al. (2008).

Other contemporary studies have employed variations of the standard sampling techniques we used in this study. Among them Al-Khatib et al. (2010) employed strata and systematic random sampling within strata to come up with sample size. Qu et al. (2009) utilized a variety of socioeconomic variables across different districts of Beijing City to derive the required number of households. Ojeda-Benitez et al. (2008) conducted residential solid waste sampling by utilizing income levels across family typology. Sujauddin et al. (2008) randomly selected 75 households in Chittagong, Bangladesh from five different socioeconomic groups to characterize household solid waste. Saeed et al. (2009) forecasted the MSW generation rate in Kuala Lumpur, Malaysia using existing data in an Excel spreadsheet. Stratified sampling across three socioeconomic groups characterized by population density, economic level and household access to public roads and utilities was used to quantify household solid waste generation in Cape Haitian, Haiti (Philippe and Culot, 2009). Similarly, other solid waste studies (Marquez et al., 2008; Sharma and McBean, 2007; Tchobanoglous et al., 1993; Troschinetz and Mihelcic, 2009) were examined for the quantitative and qualitative aspects of methodologies required for waste characterization. Sharma and McBean (2007) seemed most promising in demonstrating standard sample size calculations based on simple random sampling; however, that study is more suited for waste sampling in the field. ASTM (1998) and Dangi et al. (2008) identified appropriate techniques to derive statistically defensible sample sizes at waste disposal sites and sources of generation, respectively. Having derived the socioeconomic information of households across a geographic area with the proper sample size called for by the above studies, this manuscript bases its methods on Dangi et al. (2008).

Tchobanoglous et al. (1993) and Vesilind et al. (2002) showed that waste generation rates could vary depending on the season, month and day of the week. However, this paper utilized a one-day sampling of waste based upon the findings of Nippon Koei Co. Ltd. and Yachiyo Engineering Co. Ltd. (2005) and Dangi et al. (2008). Nippon Koei Co. Ltd. and Yachiyo Engineering Co. Ltd. (2005) did not find conventional season-specific impacts on household waste generation in KMC. Instead, they found $223 \mathrm{~g}$ capita $^{-1}$ day $^{-1}$ with $248 \mathrm{~g} \mathrm{l}^{-1}$ of bulk density among 40 households examined in April 2004 (the dry season) and $248 \mathrm{~g} \mathrm{capita}^{-1}$ day $^{-1}$ with a bulk density of $174 \mathrm{~g} \mathrm{l}^{-1}$ for 400 households studied in September 2004 (the wet season). Similarly, the daily average household waste generation in 200 KMC households did not vary much during a 14-day study conducted in December 2005 by Dangi et al. (2008). Also, the survey and sampling of waste was conducted in the shortest duration possible to minimize the effect of the rapidly changing political and physical environmental conditions in Nepal in the summer of 2007 (Bieber, 2007) as well as the difficulty of handling waste from 336 households with limited resources.

This MSW study was conducted between July 6 and July 16, 2007. The household study was conducted for one day at $336 \mathrm{KMC}$ households using a three-stage cluster sampling method in four different strata. In addition, the waste from three restaurants, three hotels and three schools was examined, as well as the litter from four $100-\mathrm{m}$ stretches of randomly selected streets to substantiate the information for a total MSW generation rate in KMC. The composition of waste from these sources is also provided. In addition to quantitative measurements of the waste at the source using standard sampling techniques, a qualitative survey and information taken from literature were also utilized to examine the generation of MSW and characterization of waste streams in KMC.

\section{Methods}

\subsection{Pilot study}

To determine statistically sound household sample size and to derive the socioeconomic information needed for the research, a pilot study of 200 households from six KMC sectors was conducted for two weeks, December 14-31, 2005. (These city sectors were chosen for strata as an initial convenience; the pilot study was used in part to collect demographic data with which to form four new strata that would more effectively parse MSW characteristics. Those new strata were then used in the subsequent field study.) It was determined that a sample size of 273 households would return results with the desired precision by entering the mean waste generation rates, standard deviations, number of households studied and total number of households for each sector into stratified sample size calculator (Scheaffer et al., 2006). With an $84 \%$ response rate, the pilot study successfully surveyed 168 of the 200 households selected. Because 273 is $84 \%$ of 325 , for the convenience of sampling purposes, 336 households were chosen for the field study. Details of the methods used in the pilot study can be found in Dangi et al. (2008, 2009).

\subsection{Field study}

The field study, conducted from June to August 2007, included 336 households selected from 20 KMC wards using a three-stage cluster sampling method (Scheaffer et al., 2006) representing four socioeconomic strata of KMC. The strata, refined using the pilot study, included low-, lower middle-, higher middle- and higherincome categories. For this study, a household was defined as a number of people using one kitchen and not by the number of rooms or house types. The distribution of sample households and other waste sources for the MSW stream are incorporated in Fig. 1, where the numbers inside the ward boundary represent the number of households selected for the study.

\subsection{Personnel, training, and equipment}

The sampling scientists who were shortlisted from the pilot study received two days of hands-on training in the safe handling of waste. The four sampling scientists engaged in characterization of household solid waste were provided with nitrile gloves, dust masks, coveralls, safety glasses, digital weighing scales (JS Ultrasport 30 or JS Ultrasport 50) and record sheets. In addition, two other sampling scientists investigated waste generation or accumulation at randomly selected restaurants (3), hotels (3) and institutions ( 3 schools) as well as street litter.

\subsection{Identification of households}

To further understand the socioeconomic status of households in the pilot study, each of the four strata were additionally screened and compared with the percentage of poor building structures in each ward according to the European Commission's Kathmandu Valley Mapping Programme (KMC, 2005). With this vetting, wards with a high percentage of poor building structures were grouped 


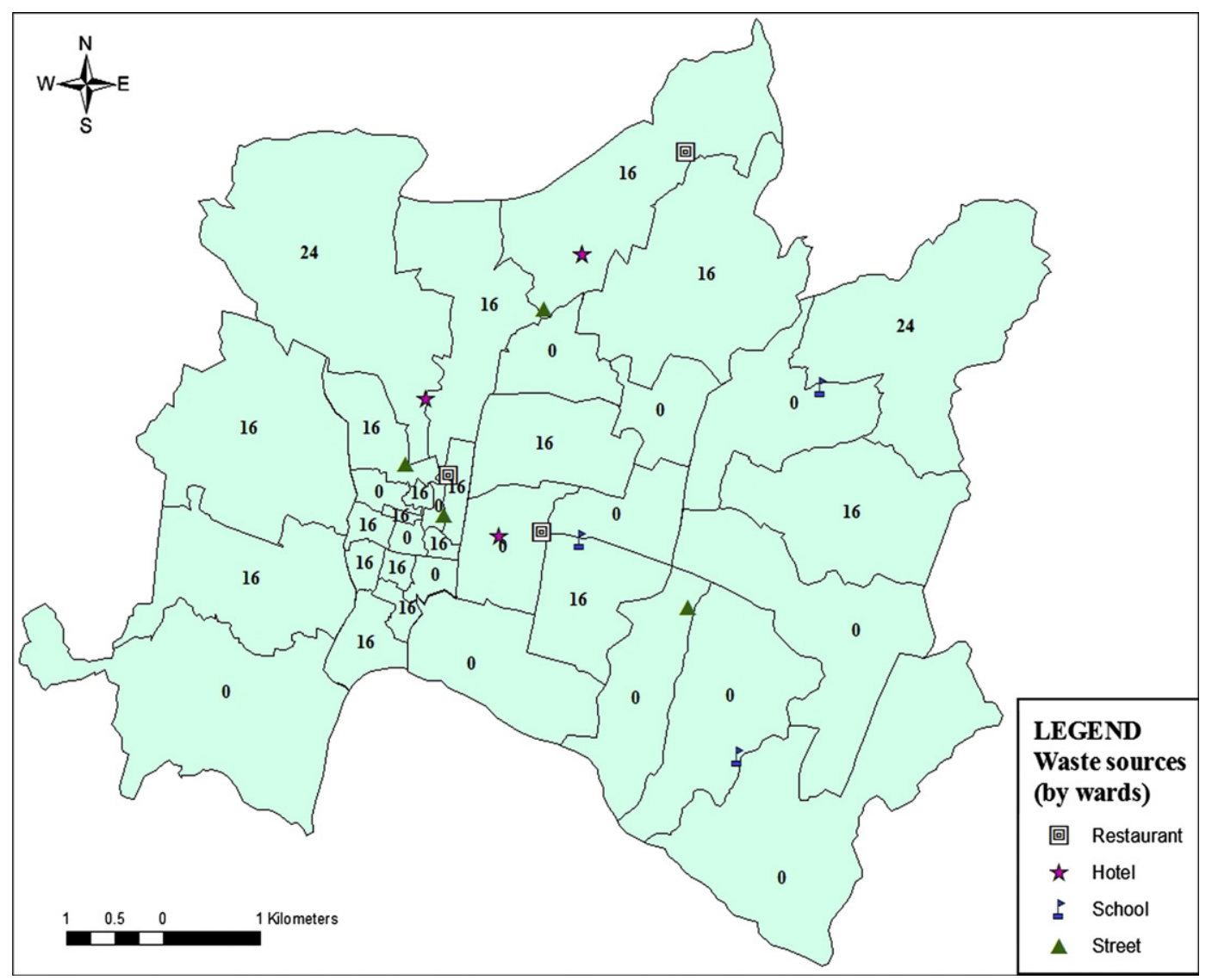

Fig. 1. Sampling map of KMC with participating households, restaurants, hotels, schools and streets.

into the low-income strata and wards with fewer poor structures were listed under higher socioeconomic brackets. Because ward 31 did not have any information about building structures, it was excluded from the study. From the remaining 34 wards, 20 wards were randomly selected for the study. Wards 3, 4, 8, 29 and 30 were placed in the higher-income stratum; wards 1, 6, 21, 23, 24, 28 and 32 made up the higher middle-income stratum; wards $12,13,15$ and 20 formed the lower middle-income stratum; and wards 16,17 , 19 and 26 constituted the low-income stratum. This created a comprehensive representation of the city.

Because the size of the stratum also dictated the number of households that were chosen, the study included 120 households from the stratum with the most wards (higher middle-income), followed by 80 households from the higher-income stratum, 72 households from the low-income stratum and 64 households from the lower middle-income stratum. More households were included from the low-income stratum than the lower middle-income stratum because of the size of the particular ward in the lowincome stratum. Upon identification of wards, 2 toles from each ward were randomly selected, except for wards 6 and 16 where 3 toles each were randomly selected. (Tole is a Nepalese word for a cluster of houses.) Then, with the identification of a focal point in that tole, a direction was randomly chosen; and from that spot, the first household positioned in that direction was selected for the study. The next household chosen for the study was seven households down and across the street from the first one. This process continued until eight households were sampled in each cluster (tole). This selection process provided equal consideration of KMC households that line up in rows on either edge of the street. In assigning toles or clusters per ward, it became necessary to allocate three clusters each to wards 6 and 16 to arrive at 336 households. Ward 16 had the largest number of households and population followed by ward 6 (KMC, 2005).

\subsection{Sampling of waste quantity}

The wastes from households, restaurants, hotels and institutions and street litter were studied separately to determine the aggregate MSW generation in KMC (Fig. 1). This common method of measuring MSW in Nepal was also employed by KMC and the Japan International Cooperation Agency (Manandhar, 2005; Nippon Koei Co. Ltd. and Yachiyo Engineering Co. Ltd., 2005). The sampling of household waste was performed the day after the survey. During the survey, the surveying scientists informed the households that their household wastes generated in a $24-\mathrm{h}$ period would be analyzed and provided two waste collection bags per household. To prevent any bias, households were not told that their waste would be sorted out. Each of the participating households deposited organic wastes, primarily kitchen and yard wastes, into the first bag while the other one was used for dry wastes (household trash). The sampling scientists collected both of the bags the next day to measure quantity (in wet weight basis) of the ten different wastes mentioned in subsection 3.1.

Connection Yellow Pages (2004) was used to identify and shortlist restaurants, hotels and institutions in KMC using simple random sampling procedures to sample waste from these sources. First, all the hotels listed in the Yellow Pages were divided into star, non-star and local types; and secondly, one hotel of each type was randomly selected for sampling. In the same way, KMC restaurants were sorted into cyber café, authentic and disco; and one of each 
kind was chosen. The classification of restaurants and hotels was verified with an experienced, independent local expert. A public high school, private boarding school and college were the institutions randomly selected for sampling. Likewise, using street map of KMC (2005), four 100-m stretches of KMC streets, one each from older KMC, a market square, a main street and a residential neighborhood, were identified using the simple random sampling procedure to quantify the street waste. The total MSW generation in KMC was determined by combining household solid waste with waste from hotels, restaurants, institutions and streets and the waste composition of the different categories was calculated using a weighted average for each source.

\section{Municipal solid waste generation}

In the field study, the survey and sampling of solid waste at 336 KMC households were designed using the results of the pilot study consisting of socioeconomic strata I, II, III and IV representing higher-, higher middle-, lower middle- and low-income family units, in that order. The allocation of households was based upon the number of toles and wards that were randomly chosen from the strata. Stratum II had the highest number of households in the study with 15 toles, followed by strata I, IV and III with 10, 9 and 8 toles, respectively.

\subsection{Household solid waste generation}

Waste from each participating household was manually segregated into organic wastes containing food and yard waste, plastics, paper and paper products, metals, glass, rubber and leather, textiles, dirt and construction debris, hazardous wastes and other wastes. This list includes all the categories of waste in the waste stream identified by KMC (Manandhar, 2005) and follows the United States Environmental Protection Agency's data on Materials Generated in Municipal Solid Waste, 1998 (Franklin, 2002). Household hazardous wastes were categorized by the types and sources defined by Nightingale and Donnette (2002): repair and remodeling wastes; cleaning agents; pesticides, herbicides and insecticides; automotive maintenance wastes and batteries; hobby and recreational wastes and other household waste chemicals. The amount of each waste category was noted by a field scientist in a data sheet and reported to the researcher later that day. The compilation of all the household waste data showed that 333 households ( 80 households from stratum I, 119 from II, 63 from III and 71 from IV) participated in the sampling, over 99\% of the 336 selected households.

The per capita waste generation of each household was calculated by dividing the total waste produced with the number of people living in that household that day. This way, the strata were differentiated with their own waste generation patterns, which were then plotted in histograms using SPSS 15.0. A sample histogram for household waste from stratum III is provided in Fig. 2. From the histograms, mean household waste generation rates of 240.7, 198.4, 162.9 and $1584.1 \mathrm{~g} \mathrm{capita}^{-1}$ day $^{-1}$ were identified for strata I through IV, respectively. The corresponding standard deviations for waste generation were 193.6, 152.2, 129 and 11,580.1. The generation of organic wastes and plastics differed significantly among the four strata. Fig. 3 shows a sample histogram for organic waste. From the histograms, the mean organic wastes and plastics generation rates are 708 and $113.3 \mathrm{~g} \mathrm{day}^{-1}$, respectively. The standard deviation for organic wastes is 639 , and it is 212.8 for plastics.

The positive relationship between income and waste generation rate established in the pilot study (Dangi et al., 2008) held in all the strata except in stratum IV. The mean of waste generation and the

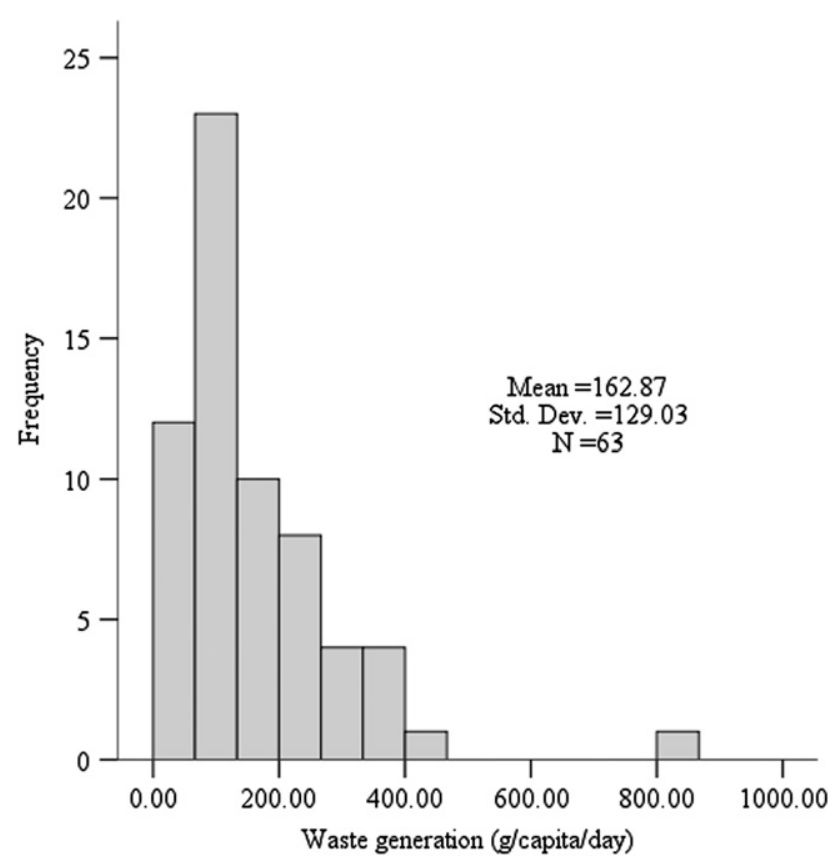

Fig. 2. Histogram for waste generation in stratum III (lower middle-income).

values for standard deviation were in descending order for strata I-III, but the value peaked quickly for stratum IV. Stratum IV, housing ward 16, the largest ward, has a plethora of open spaces and rural neighborhoods (KMC, 2005) plus high construction activities. Household number 268 in ward 16 had a pile of cement and brick wastes from a new structure and because of this the household had an exceptionally high rate of waste generation $\left(97,758.2\right.$ g capita $^{-1}$ day $\left.^{-1}\right)$. Stratum IV produced the highest amount of dirt and construction debris (7.7\% with household 268 included and $6.3 \%$ without it). This may explain why stratum IV had the greatest quantity of waste generation.

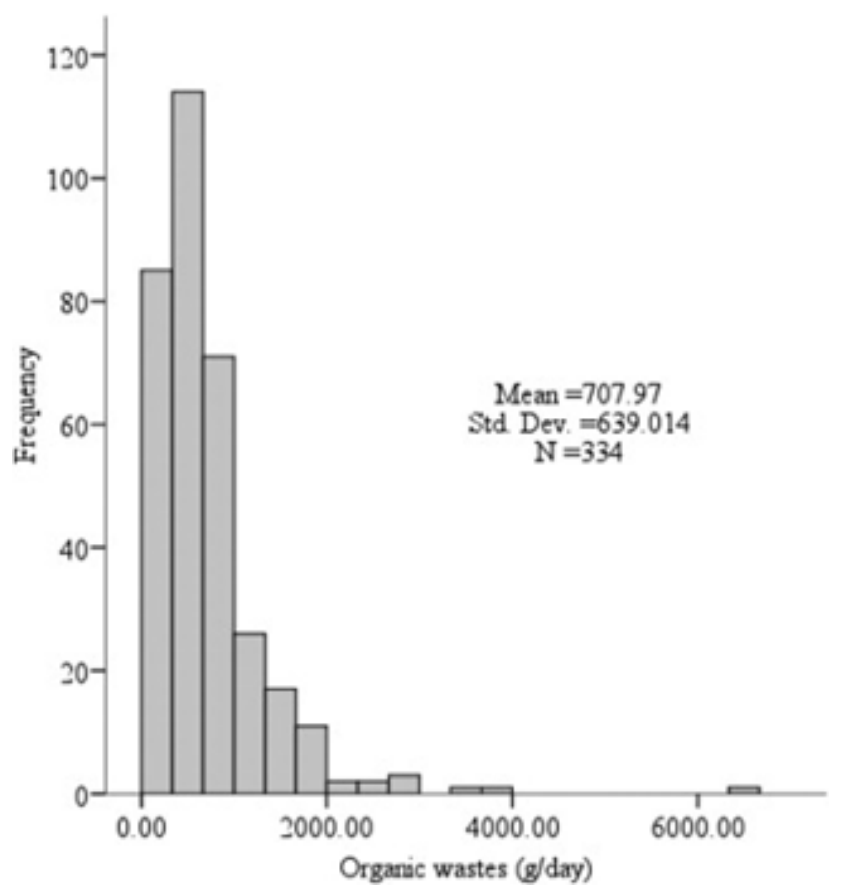

Fig. 3. Histogram for organic wastes. 
The total waste generation rate from households and quantity of waste types produced from each stratum were individually entered into a SAS 9.1 statistical package, where assumptions for conducting an analysis of variance (ANOVA) were tested. Their corresponding histograms showed that each data set was highly skewed, indicating gross violations of the normality assumption as also evidenced by the $p$-values associated with the Shapiro-Wilk's test statistic (each $p$-value $<0.0001$ ). Though the $p$-values for the Levene's test for equality of variance were greater than the critical alpha level of 0.05, ANOVA was an inappropriate tool because of the presence of non-normal data. Instead, the Kruskal-Wallis test was utilized followed by post-hoc analyses based on ranks.

The Kruskal-Wallis test is applicable in the presence of positively skewed data or any data that is skewed as long as the skew for all of the group points are in the same direction, i.e. the shapes of the distributions take on a similar appearance. The waste generation distributions for each individual stratum and for organic wastes and plastics are skewed to the right as depicted by two of the histograms (Figs. 2 and 3). Furthermore, when random samples were collected from all households, mutual independence among selected households was maintained and the scale of measurement was at least ordinal, therefore, the Kruskal-Wallis test was applicable for analysis because certain household populations yielded greater generation rates (mean or median generation rates) than others (Conover, 1980). The examination of the waste generation rate and quantity of all waste types from households revealed significant differences among the strata in the per capita waste generation rate, organic wastes and plastics. For the per capita household waste generation rate, the results indicate a difference in waste generation rates between higher- and lower middle-income residents and between higher- and low-income residents. The $p$-values for them were all below 0.1 , the critical alpha value for the post-hoc test based on ranks of the data (Table 1 ).

The skewness and kurtosis calculated were 18.2 and 332.1. The total mean for household waste generation was $204.3 \mathrm{~g} \mathrm{capita}^{-1}$ day $^{-1}$ without household 268 and $497.3 \mathrm{~g} \mathrm{capita}^{-1}$ day $^{-1}$ with it. The positive value of skewness (18.2) indicates that the curve tailed off more toward the right. It is reasonable that waste generation amounts are skewed to the right, meaning there can be no less than $0 \mathrm{~g} \mathrm{capita}^{-1} \mathrm{day}^{-1}$ of waste generation on any given day, but there is practically no upper limit.

The results showed differences between higher- and lowincome strata in the generation of organic wastes and between higher middle- and low-income strata in plastics. This suggests that the types of meals prepared at homes and vegetable and other organic wastes discarded differed between higher- and low-income strata. Also, the quantity of plastics disposed of is dependent upon the wealth of the strata. Table 1 also includes the mean, standard deviation, skewness and kurtosis in all strata for organic wastes (708, 639, 3.6 and 23.8, respectively) and plastics (113.3, 212.8, 10.1 and 142.2, respectively). The values of skewness and kurtosis align with those values for waste generation among strata. Only the strata and waste streams with significant differences were

Table 1

Statistical parameters for waste generation (g/capita/day) for strata, organic wastes (g/day) and plastics (g/day).

\begin{tabular}{llll}
\hline Statistical parameters & Strata & Organic wastes & Plastics \\
\hline Sample size $(=n)$ & 333 & 334 & 334 \\
Mean & 497.3 & 708 & 113.3 \\
Standard deviation & 5349.4 & 639 & 212.8 \\
Skewness & 18.2 & 3.6 & 10.1 \\
Kurtosis & 332.1 & 23.8 & 142.2 \\
Significance & I and III; I and IV & I and IV & II and IV \\
\hline
\end{tabular}

presented in Table 1. Also, the median value of household waste generation (160.5) is lower than the mean. This is consistent with the positively skewed distribution of waste data. Fig. 4 depicts the distribution of waste generation within strata without household number 268. The relationship between daily household waste generation and the number of people residing in participating KMC households is provided in Fig. 5, minus the extreme outliers in the high end of waste generation to better show the waste data. The majority of household generation falls around 5.7, the average family size for KMC determined from the field study. Overall, the per capita waste generation rate decreased with an increase in family size and the household waste generation rate went up with larger families.

As found in the pilot study (Dangi et al., 2008), waste generation leveled off in decreasing order from wealthier strata to less well-off strata (from higher- to lower middle-income), but the trend did not hold for the least well-off strata (low-income) (Fig. 4). The numbers may not have followed the pattern seen in the pilot study because this stratum had an overall high generation of dirt and construction debris. The one-day sampling of households in the field study and restructuring of strata after the pilot study may also account for the change. The pilot study conducted a two-week rigorous sampling that contributed to stabilize waste generation numbers. In addition, some degree of high skewness is common in waste generation data in solid waste studies (Tchobanoglous et al., 1993) and ignoring this fact could bring the dirt and construction debris' numbers into question. Therefore, $497.3 \mathrm{~g} \mathrm{capita}^{-1} \mathrm{day}^{-1}$ is used as a measure for overall average household waste generation in this research. With this rate of $497.3 \mathrm{~g}$ capita $^{-1}$ day $^{-1}$, the field study found 393.2 metric tons day ${ }^{-1}$ of household waste in KMC based on its population of 790,597 (All Countries, 2006).

\subsection{Waste generation from other sources}

The average waste generation measured was $48.5 \mathrm{~kg} \mathrm{day}^{-1}$ from restaurants, $113.3 \mathrm{~kg} \mathrm{day}^{-1}$ from hotels and $26.1 \mathrm{~kg} \mathrm{day}^{-1}$ from schools. Restaurants produced 15.6 metric tons day ${ }^{-1}$ of wastes, hotels produced 30.7 and schools produced 15 . The latest data show 322 restaurants, 271 hotels and 577 schools in KMC (Connection Yellow Pages, 2004).

The average amount of street litter accumulated was $61,115.9 \mathrm{~g}$ $100 \mathrm{~m}^{-1}$ day $^{-1}$ of street length. Given the total road length of $794.1 \mathrm{~km}$ in KMC (SWMRMC et al., 2004), 485.3 metric tons of street litter can accumulate in a day. Because that number was much higher than expected, KMC sweepers working that day were contacted and they reported that the streets had not been swept for a week because of shutdown of landfill. So, an average of 69.3 metric tons day ${ }^{-1}$ of street litter was obtained by dividing the total street litter by seven.

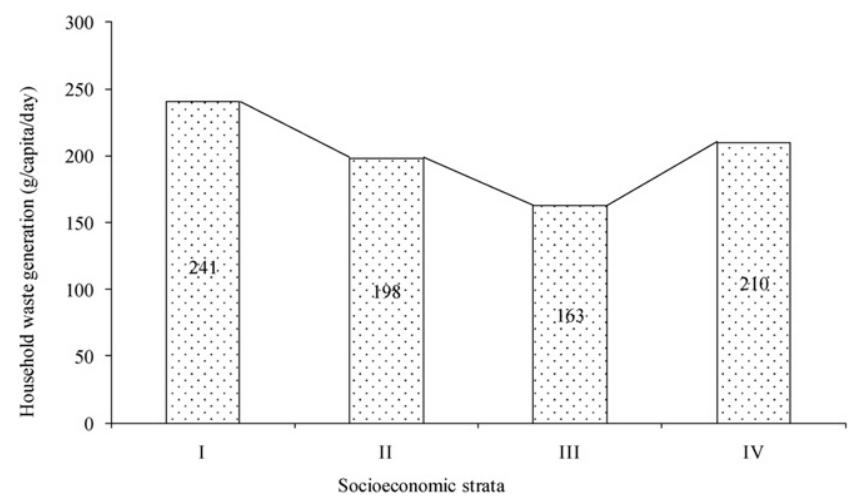

Fig. 4. Waste generation among strata without household number 268 . 


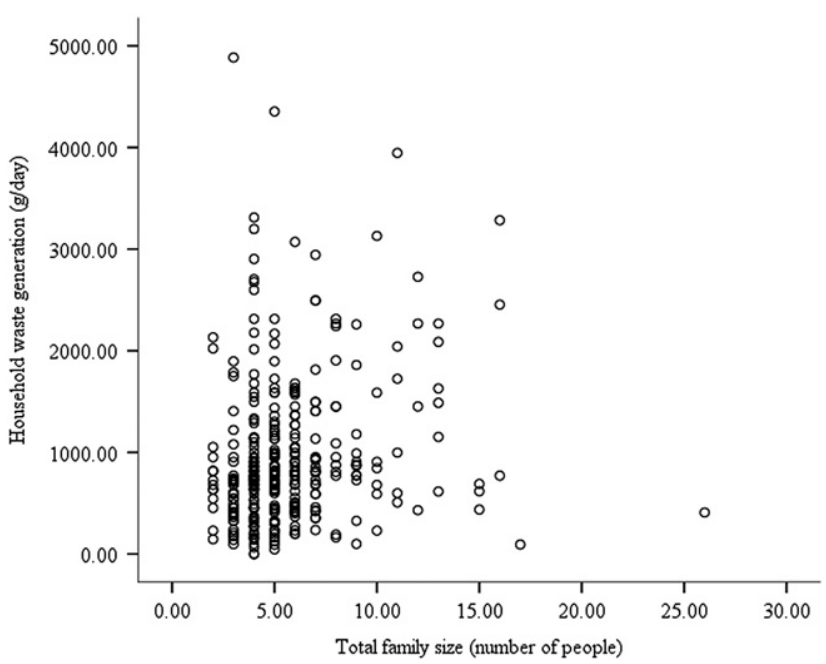

Fig. 5. Relationship between household waste generation and family size.

\section{Municipal solid waste composition}

The waste sampled from households, restaurants, hotels, institutions and streets was segregated into ten types to investigate composition, shown in Figs. 6-10. For household waste (Fig. 6), the largest proportion was organic wastes (71\%) and rubber and leather was the smallest $(0.3 \%)$. Plastics $(12 \%)$, paper and paper products (7.5\%) and dirt and construction debris (5\%) followed the organic wastes. The amounts of glass, hazardous wastes, textiles, other wastes and metals were greater than rubber and leather. The hazardous wastes stream measured significantly more at $1 \%$ than the $0.4 \%$ obtained in the pilot study.

The composition of restaurant waste (Fig. 7) was made up of $53.4 \%$ organic wastes, $31.6 \%$ glass, $5.3 \%$ paper and paper products, $5.1 \%$ plastics, $2.2 \%$ other wastes, $1.5 \%$ textiles and $0.9 \%$ metals. The waste stream characteristics for rubber and leather, dirt and construction debris and hazardous wastes were all zero. The absence of dirt and construction debris and rubber and leather reflect the nature of waste streams generally found in restaurants and the very high rate of glass wastes record the discarded beer and wine bottles observed at the time of sampling.

The waste stream for hotels ranged from $57.8 \%$ organic wastes to $0 \%$ rubber and leather and hazardous wastes (Fig. 8). The remaining waste was composed of metals (16.9\%), plastics (9.6\%), glass (8.8\%), paper and paper products (3.3\%), other wastes (1.7\%), dirt and construction debris (1.6\%) and textiles (0.4\%). The high levels of

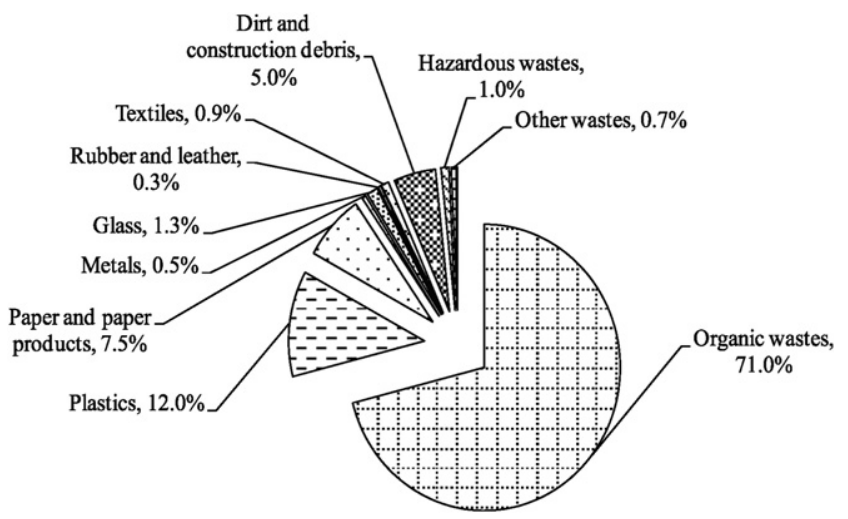

Fig. 6. Composition of household waste in KMC.

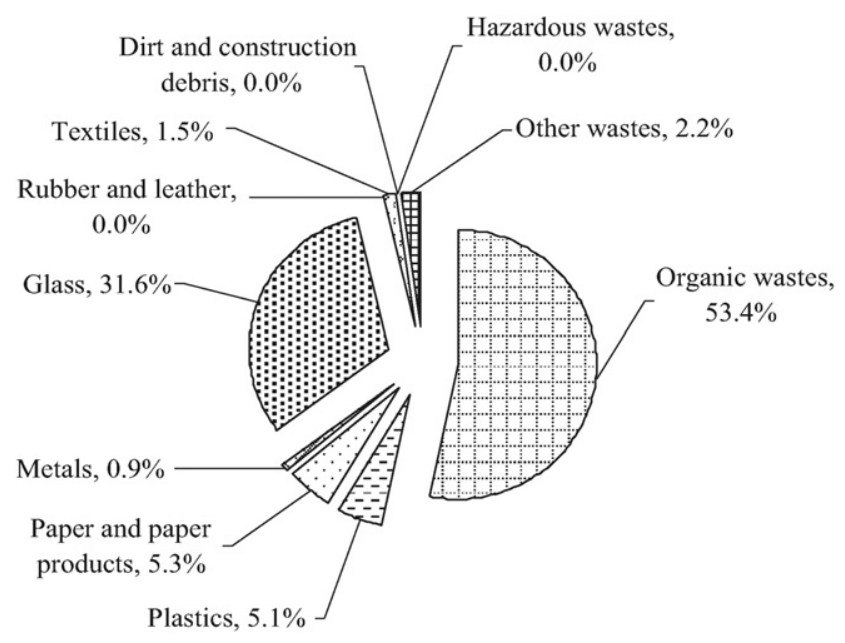

Fig. 7. Composition of restaurant waste in KMC.

metals, glass and plastics indicate the presence of aluminum cans, beer bottles and packaged food items used by hotel guests.

School wastes were categorized as institutional wastes. The composition analysis uncovered $38.6 \%$ organic wastes, $20.3 \%$ plastics, $17.3 \%$ dirt and construction debris, $12.7 \%$ paper and paper products and 3.5\% other wastes with textiles, metals and rubber and leather all below 3\% (Fig. 9). Glass and hazardous wastes were not found in the school waste. Generally, a low level of organic wastes was found in school waste because there was little handling of fresh food. The dirt and construction debris contained dust and broken bricks. The significant amount of plastics and paper and paper products came from students' snack boxes and discarded white paper.

Street waste was composed of all ten types of wastes studied in the research. The characteristics of the street waste ranged from $0.8 \%$ for rubber and leather to $63.7 \%$ for organic wastes (Fig. 10). Paper and paper products (10.2\%), plastics (8.8\%), dirt and construction debris (5.8\%), textiles (3.8\%) and glass (2.7\%) were part of the waste composition in street waste. Metals, other wastes and hazardous wastes were all below $2 \%$. It is likely that all the types of waste were found in the street because of the unavailability of containers and dustbins along sidewalks and intersections. Street litter presented a representative picture of waste data for the city because all the values lie within the range outlined above for different waste types studied at the sources of generation.

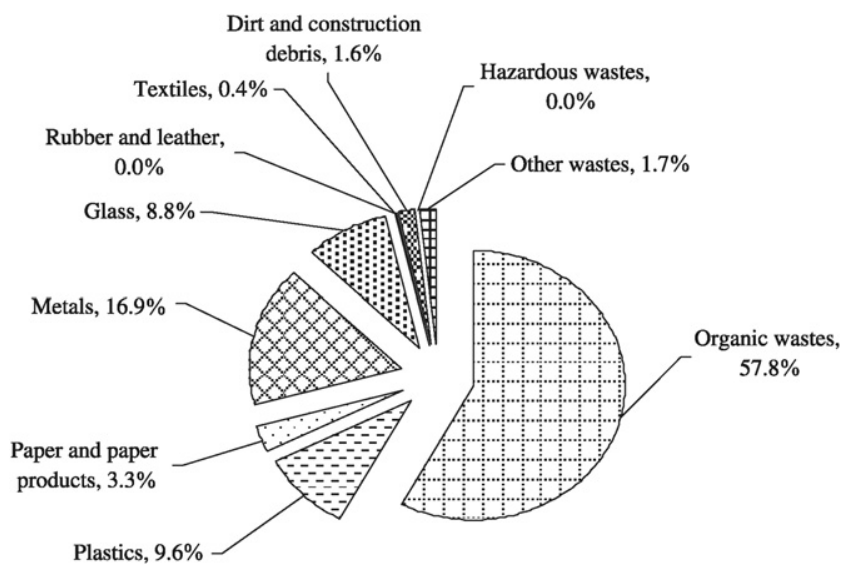

Fig. 8. Composition of hotel waste in KMC. 


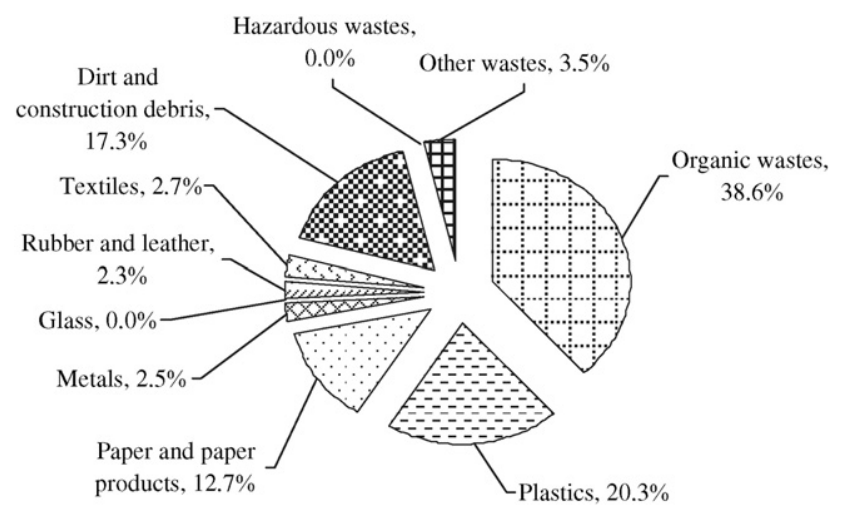

Fig. 9. Composition of school waste in KMC.

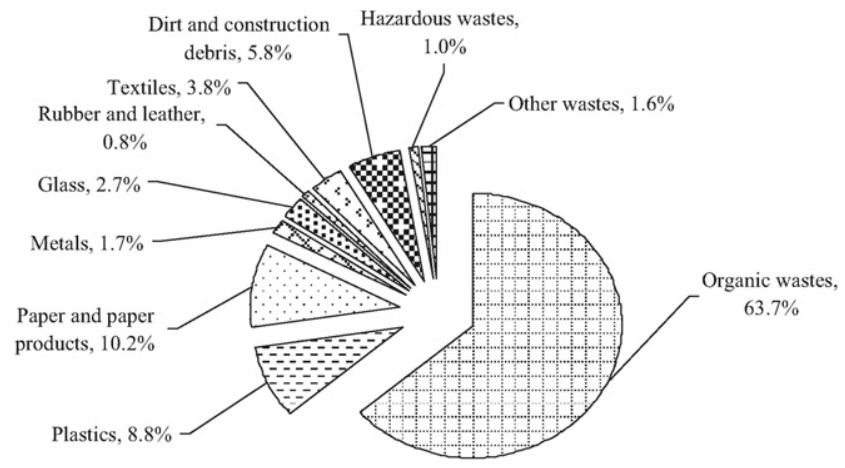

Fig. 10. Composition of street waste in KMC.

Organic wastes was the largest waste stream in all five sources of waste investigated, varying from a high of $71 \%$ in household waste to a low of $38.6 \%$ in school waste. The $1 \%$ of hazardous wastes found in the household waste was replicated in the street waste, confirming the observation that hazardous wastes generation in $\mathrm{KMC}$ is increasing.

\section{Comparison of waste stream characteristics and generation}

The household waste stream characteristics found were in line with other studies conducted in KMC and Patan, the two largest cities in the Kathmandu Valley (Table 2). The portion of organic waste found in the studies is consistently approximately $2 / 3$ of the total waste. Dangi et al. (2008) obtained a lower number, $62.9 \%$, because the pilot study was conducted for two weeks at the participating households, thus leading to more accurate measurements of waste characteristics. Generally, plastics and paper and paper products have gone up with a steady increase in the weight percentage. Dirt and construction debris found in the field study was less than in many other studies. The firm increase of dirt and construction debris gathered in the data for the strata (3.3-7.7\%) in the field study support a gradual increase of construction activities as the strata extended out from the core of KMC where there are open spaces. Also, the large sample size $(n=336)$ of this research in comparison to other studies may have led to more reliable estimates of dirt and construction debris.

An important finding of this research is the rising prevalence of hazardous wastes $(0.4 \%$ in 2005 vs. $1 \%$ each in the household solid waste and street litter from the field study). The research found the same percentage of hazardous waste in the household and street litter samples, supporting the above observation. Hazardous waste as represented by dry cell batteries was at $0.2 \%$ in Khanal's (1993)
Table 2

Chronology of waste composition.

\begin{tabular}{|c|c|c|c|c|c|c|c|}
\hline \multirow[t]{2}{*}{ Waste types } & \multicolumn{7}{|c|}{$\%$ waste composition by weight } \\
\hline & $1976^{\mathrm{a}}$ & $1985^{\mathrm{b}}$ & $1993^{c}$ & $2001^{\mathrm{d}}$ & $2004^{\mathrm{e}}$ & $2005^{f}$ & $2007^{\mathrm{g}}$ \\
\hline Organic wastes & 67.8 & 67.5 & 66.5 & 69.0 & 71.1 & 62.9 & 71.0 \\
\hline Plastics & 0.3 & 2.6 & 5.4 & 9.0 & 6.5 & 5.4 & 12.0 \\
\hline Paper and paper products & 6.5 & 6.0 & 7.3 & 9.0 & 9.2 & 4.5 & 7.5 \\
\hline Metals & 4.9 & 2.2 & 2.2 & 1.0 & 0.6 & 1.2 & 0.5 \\
\hline Glass & 1.3 & 4.0 & 3.1 & 3.0 & 5.1 & 2.1 & 1.3 \\
\hline Rubber and leather & 0.0 & 0.0 & 1.6 & 1.0 & 0.0 & 0.8 & 0.3 \\
\hline Textiles & 6.5 & 2.7 & 1.7 & 3.0 & 2.4 & 1.7 & 0.9 \\
\hline Dirt and construction debris & 10.0 & 15.0 & 10.8 & 2.0 & 0.0 & 18.8 & 5.0 \\
\hline Hazardous wastes & & & 0.2 & & & 0.4 & 1.0 \\
\hline Wood & 2.7 & 0.0 & 1.1 & & 3.1 & & \\
\hline Other wastes & & & & 3.0 & 2.0 & 2.1 & 0.7 \\
\hline Total & 100.0 & 100.0 & 100.0 & 100.0 & 100.0 & 100.0 & 100.0 \\
\hline \multicolumn{8}{|c|}{$\begin{array}{l}\text { a Tabasaran, } 1976 . \\
\text { b Mutz cited in UNEP et al. (2001) } \\
\text { c Khanal, } 1993 . \\
\text { d Manandhar, } 2005 . \\
\text { e Nippon Koei Co. Ltd. and Yachiyo Engineering Co. Ltd. (2005). } \\
\text { f Dangi et al., 2008. }\end{array}$} \\
\hline
\end{tabular}

study. Moreover, citing KMC in KMC and World Bank (2001), the hazardous wastes represented by batteries was at $0.6 \%$ of the total wastes in 1995. The lack of legislation regulating these wastes in Nepal (UNEP et al., 2001) may contribute to the increase.

The percent by weight of the waste identified by the field study is also within the range of urban waste characteristics for lowincome countries specified by the World Bank (Cointreau, 2006). The study recommended that vegetable/putrescible wastes lie between 40 and $85 \%$ of the total waste with paper and carton at $1-10 \%$, plastic at $1-11 \%$, metal at $1-5 \%$, glass at $1-10 \%$, rubber at $1-3 \%$ and fines such as sand, ash and broken glass at $15-50 \%$. The low percentage of metals, rubber and fines in the field study may be the result of informal waste picking via separation at or near to source, which removes most of the recyclable items, and/or the nature of the waste stream compared to the World Bank data (i.e. household waste). This corroborates recent findings in KMC, where some households have started segregating MSW at source (Thakali and Karki, 2010).

Also, the waste stream characteristics for KMC are comparable with several of the 23 Indian cities discussed in Sharholy et al. (2008). KMC's numbers for household waste and street litter were similar to that of Calcutta (reported in wet weight basis), where paper, textile, leather, plastics, metals and glass were $10 \%$, $3 \%, 1 \%, 8 \%, 0 \%$ and $3 \%$, respectively. Ash, fine earths and others totaled $35 \%$ and the remaining $40 \%$ was compostable matter. The study further described that the overall compostable fraction of MSW ranged between 40 and $60 \%$ and the share of recyclables had fallen with enhanced recovery via informal sectors. This was particularly true with metals in many of the Indian cities. Comparatively, the low presence of metals and glass in household waste and street litter in KMC further supports the effectiveness of informal waste picking and separation near to source.

Though the average household waste generation of $204.3 \mathrm{~g} \mathrm{capita}^{-1}$ day $^{-1}$ without household 268 and the median of $160.5 \mathrm{~g} \mathrm{capita}^{-1} \mathrm{day}^{-1}$ were reasonably close to the $161.2 \mathrm{~g} \mathrm{capita}^{-1}$ day ${ }^{-1}$ found in the pilot study, the actual average of $497.3 \mathrm{~g}$ capita $^{-1}$ day $^{-1}$ was higher in the field study. When this daily household solid waste generation rate was combined with wastes from restaurants, hotels, schools and streets, KMC produced $0.66 \mathrm{~kg} \mathrm{capita}^{-1} \mathrm{day}^{-1}$ or 523.8 metric tons of total MSW per day.

Among the different studies that have identified per capita waste generation in KMC, Manandhar (2005) estimated 0.35 
$\mathrm{kg}$ capita $^{-1}$ day $^{-1}$ of MSW generation in KMC. More recently, Manandhar (2006) reported that KMC generated $0.4 \mathrm{~kg}_{\text {capita }}{ }^{-1}$ day $^{-1}$ of waste from household, commercial, institution and surrounding village sources. This number doesn't account for the unorganized discharge of uncollected wastes along the sidewalks and streets, in corners and on any vacant land. Fig. 11 provides a comparison of some of these studies with the field study. Rates in the other studies ranged from $0.4 \mathrm{~kg}_{\text {capita }}{ }^{-1}$ day $^{-1}$ (Tabasaran, 1976) to $0.52 \mathrm{~kg}_{\text {capita }}{ }^{-1} \mathrm{day}^{-1}$ (SWMRMC et al., 2004). This study reported $0.66 \mathrm{~kg}_{\text {capita }}{ }^{-1} \mathrm{day}^{-1}$ for KMC.

The methods and statistical precision used by these studies differ, as do the durations of the studies. Tabasaran (1976) established waste generation in KMC from his experience in other countries without any actual physical sampling; Khanal (1993) projected waste generation in Kathmandu Valley assuming that $30 \%$ of waste was household waste; Manandhar (2005) assumed that out of $0.35 \mathrm{~kg} \mathrm{capita}^{-1} \mathrm{day}^{-1}, 0.1 \mathrm{~kg} \mathrm{capita}^{-1}$ day $^{-1}$ consisted of wastes from streets, institutions and villages, using 2001 waste information; and SWMRMC et al. (2004) extrapolated $0.39 \mathrm{~kg}$ capita $^{-1}$ day $^{-1}$ of household waste assuming that it made up $75 \%$ of total MSW. So, these studies don't agree on per capita waste generation rates in KMC (Bhattarai, 2003).

Manandhar (2006) reported 320 metric tons day ${ }^{-1}$ of MSW for KMC for 2006 and this number was 249 metric tons day ${ }^{-1}$ in 2001 (Manandhar, 2005). SWMRMC et al. (2004) derived 384 metric tons day $^{-1}$ in July 2003; and Nippon Koei Co. Ltd. and Yachiyo Engineering Co. Ltd. (2004) obtained 308.4 metric tons day ${ }^{-1}$. Also, Pradhan (2002) cited KMC in reporting 420 metric tons day ${ }^{-1}$ of waste generation in KMC. Considering these numbers, 523.8 metric tons a day in July 2007 is within par. Given KMC's substantial increase in population after more than a decade of internal conflict in Nepal and the dissimilarity of the procedures employed by the studies, these numbers are justifiable and the per capita waste generation $\left(0.66 \mathrm{~kg} \mathrm{capita}^{-1}\right.$ day $\left.^{-1}\right)$ is within the normal range for capital cities in developing countries. Table 3 (Glawe et al., 2005) compares the waste generation rates of some developing countries and cities with KMC. Though the number for KMC is higher than some, it is close to others. Also, more construction activities combined with the escalating population in KMC may account for the higher waste generation rate.

Because waste generation depends upon population density, economic development, proportion of urban population and consumption pattern (Glawe et al., 2005; Vesilind et al., 2002), the somewhat increased waste generation rate in the field study is logical given KMC's changes in land use and the largest expansion
Table 3

Comparison of waste generation among developing countries/cities.

\begin{tabular}{ll}
\hline Cities/Countries & Waste generation $\left(\mathrm{kg} \mathrm{capita}^{-1}\right.$ day $\left.^{-1}\right)$ \\
\hline Bhutan & 0.30 \\
Kabul, Afghanistan & 0.40 \\
Myanmar & 0.45 \\
Bangladesh & 0.50 \\
Maldives & 0.66 \\
Kathmandu, Nepal & 0.66 \\
Laos PDR & 0.75 \\
Cambodia & 1.00 \\
Thailand & 1.00 \\
\hline
\end{tabular}

of urban population among Kathmandu Valley municipalities from 1991 to 2001 (7.9\%). A land use map of urban built-up areas, orchards, natural vegetation, cultivated land and water in KMC shows that the urban built-up area increased by $17 \%$ from 1989 to 2005 , and cultivated land decreased from $36 \%$ to $17 \%$ during this period (Thapa and Murayama, 2006). KMC and World Bank (2001) cited KMC in reporting that in 19953273 ha of KMC's total area of 5076 ha were used for residential and commercial purposes and 1314 ha were open space including vacant land, squatters and important designated areas. Moreover, Pradhan (2004) reported that the urban built-up area in Kathmandu Valley grew by $212 \%$ from 1955 to 1996 and the population climbed by 608\% from 1952/ 54 to 2001. In addition, the size of the city in a low-income country may dictate the per capita waste generation. KMC is the largest city in Nepal with more than 500,000 people producing mixed urban waste, so its waste generation rate should fall within $0.5-0.75 \mathrm{~kg}_{\text {capita }}^{-1}$ day $^{-1}$ (Cointreau, 2006). This categorization does not include construction and demolition wastes, thus $0.66 \mathrm{~kg} \mathrm{capita}^{-1} \mathrm{day}^{-1}$, including dirt and construction debris, is well within the range of international comparisons.

Within Nepal, there is a strong linear correlation between population size and yearly waste generation, which was measured at 0.94 in KMC using data from Table 4 . Also, Table 4 shows an equivalent increase in the quantity of waste with the increase in population from 1952/54 to 1981. After 1981, the percentage increase in population was roughly equal to the percentage increase in waste generation until 1991; however, from 1991 to 2001 the percentage increase in population was about double the percentage increase in waste generated. Using an average of the percentage increase in waste from 1971 to 1991 to calculate the waste generation for 2001 results in a projected 105,995 metric tons of waste. Using the same percentage increase to extrapolate waste for 2011

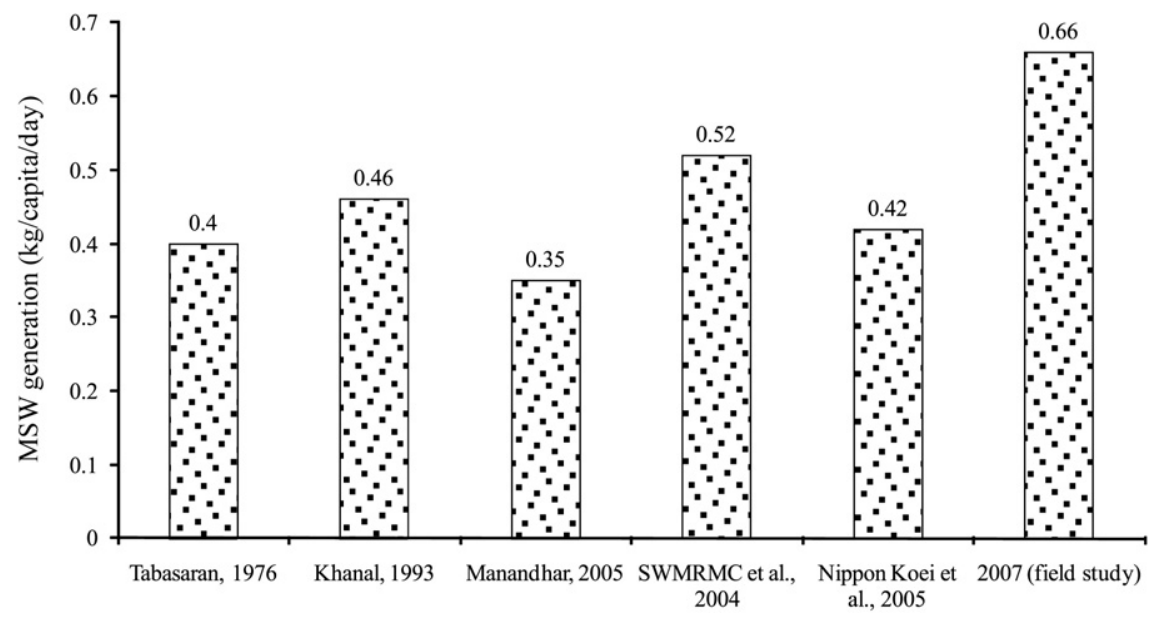

Fig. 11. Comparison of waste generation rate in KMC. 
Table 4

Population growth and solid waste generation in metric tons (m.t.) in KMC for 1952/54-2007.

\begin{tabular}{|c|c|c|c|c|c|c|c|c|}
\hline \multirow[t]{2}{*}{ Element } & \multicolumn{8}{|l|}{ Year } \\
\hline & $1952 / 54$ & 1961 & 1971 & 1981 & 1991 & 2001 & 2003 & 2007 \\
\hline Population & $106579^{a}$ & $121019^{\mathrm{a}}$ & $150402^{\mathrm{a}}$ & $235160^{b}$ & $421258^{\mathrm{b}}$ & $671846^{c}$ & $741008^{d}$ & $790597^{e}$ \\
\hline Annual waste (m.t.) & $17905^{f}$ & $20331^{\mathrm{f}}$ & $25268^{f}$ & $39507^{f}$ & $69596^{\mathrm{f}}$ & $90885^{g}$ & $140160^{\mathrm{h}}$ & $191187^{\mathrm{i}}$ \\
\hline Increase in population & & $13.5 \%$ & $24.3 \%$ & $56.4 \%$ & $79.1 \%$ & $59.5 \%$ & $10.3 \%$ & $6.7 \%$ \\
\hline Increase in waste & & $13.5 \%$ & $24.3 \%$ & $56.4 \%$ & $76.2 \%$ & $30.6 \%$ & $54.2 \%$ & $36.4 \%$ \\
\hline \multicolumn{9}{|l|}{ 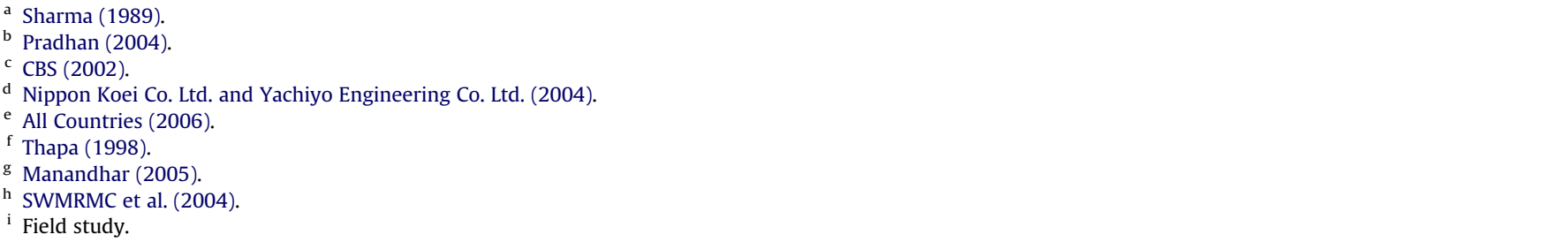 } \\
\hline
\end{tabular}

results in a projected 161,430 metric tons of wastes. Then, if the percentage increase in waste generation for 2001-2003 is used, the calculated waste in 2007 would be at 216,127 metric tons. Thus, the 191,187 metric tons calculated in the field study for the year 2007 appears reasonable for KMC based on the observed waste trends in Nepal as well as comparisons with international findings for the largest city in a low-income country (Cointreau, 2006). Also, using the accurate population of the city for July 2007 (time of sampling) and treating dirt and construction debris as special wastes and handling that category separately, as it is done in developed countries (Tchobanoglous, 2002), will reduce the metric tons of MSW reported for KMC.

\section{Conclusions and recommendations}

Accurate measurement of waste generation and characteristics is vital to improve solid waste management practices. This study used three-stage stratified cluster sampling method to examine household solid waste generation in KMC, which when combined with other waste sources observed using simple random sampling procedure provided total MSW generation rate of $0.66 \mathrm{~kg}$ capita $^{-1}$ day $^{-1}$. This information can be used to study other Nepalese municipalities. The waste generation rate and composition analysis suggests that composting the organic fraction of MSW should be carefully considered and effective waste management in KMC will require very detailed examination of waste reduction strategies. The presence of a large fraction of recyclable items throughout different sources of MSW such as paper and paper products, plastics, metals and glass also point toward the possibility of expanding traditional waste picking as a form of resource recovery. The fraction associated with construction debris implies that it too can be utilized as exchange at the sources or materialized as filling substance in construction and expansion of roads. In addition, the trend of increasing hazardous waste will demand carefully designed policies and procedures for its management. With thorough separation of MSW at the source and waste specific treatment, KMC could achieve safe and high quality organic compost while diverting a large fraction of solid waste from landfills.

\section{Acknowledgements}

The study was funded by Francois Fiessinger Fellowship of Environmental Research and Education Foundation. The authors acknowledge comments provided by Professors Erica Schoenberger and John J. Boland. Special thanks goes to Tribhuvan University faculty and students for their assistance in the field study. The paper is dedicated to the memory of Professors M. Gordon Wolman and Philippe Ross and Principal Madam Manorama Rana for their support and inspiration.

\section{References}

Al-Khatib, I.A., Monou, M., Abu Zahra, A.S.F., Shaheen, H.Q., Kassinos, D., 2010. Solid waste characterization, quantification and management practices in developing countries. A case study: Nablus district - Palestine. Journal of Environmental Management 91, 1131-1138.

All Countries, 2006. Population of Kathmandu. Retrieved 04.07.08. from. http:/ population-of.com/en/Nepal/00/Kathmandu/.

American Society of Testing and Materials (ASTM), 1998. Standard Test Method for Determination of the Composition of Unprocessed Municipal Solid Waste. ASTM Standard D 5231-92 (Reapproved 1998), West Conshohocken, PA, USA.

Asian Development Bank, 2006. Technical assistance report, Nepal: preparing the Kathmandu valley water distribution, sewerage, and urban development project. Retrieved 26.06.09. from. http://www.adb.org/Documents/TARs/NEP/ 34304-NEP-TAR.pdf.

Bhattarai, R.C., 2003. Economics of Solid Waste Management: A Case Study of Kathmandu Metropolis. Unpublished Doctoral Dissertation, Tribhuvan University, Kirtipur, Nepal.

Bieber, S., April 2, 2007. Personal Communication.

Central Bureau of Statistics (CBS), 1991. Area and Population. HMG Nepal, Kathmandu, Nepal.

CBS, 2002. Statistical Pocket Book Nepal 2002. National Planning Commission Secretariat, Kathmandu, Nepal.

Cointreau, S., 2006. Occupational and Environmental Health Issues of Solid Waste Management: Special Emphasis on Middle- and Lower-Income Countries. World Bank, Washington, DC. Retrieved 26.06.09. from. http://siteresources. worldbank.org/INTUSWM/Resources/up-2.pdf.

Connection Yellow Pages, 2004. Connection Yellow Pages 2004, twelfth ed Development Publication House (P) Ltd., Kathmandu, Nepal.

Conover, W.J., 1980. Practical Nonparametric Statistics, second ed. John Wiley and Sons, New York, USA.

Dangi, M.B., 2009. Solid Waste Management in Kathmandu, Nepal: The Anatomy of Persistent Failure. Published Doctoral Dissertation, the Johns Hopkins University, Baltimore, MD. ProQuest LLC, Ann Arbor, MI, USA.

Dangi, M.B., Cohen, R.R.H., Urynowicz, M.A., Poudyal, K.N., 2009. Searching for a way to sustainability: technical and policy analyses of solid waste issues in Kathmandu. Waste Management and Research 27, 295-301.

Dangi, M.B., Urynowicz, M.A., Gerow, K.G., Thapa, R.B., 2008. Use of stratified cluster sampling for efficient estimation of solid waste generation at household level. Waste Management and Research 26, 493-499.

Franklin, M.A., 2002. Solid waste stream characteristics. In: Tchobanoglous, G. Kreith, F. (Eds.), Handbook of Solid Waste Management, second ed. McGrawHill, New York, USA, pp. 5.1-5.30.

Glawe, U., Visvanathan, C., Alamgir, M., July 5-7, 2005. Solid waste management in least developed Asian countries - a comparative analysis. In: Proceedings of International Conference on Integrated Solid Waste Management in Southeast Asian Cities. Asian Institute of Technology, Bangkok, Thailand.

Kathmandu Metropolitan City (KMC), 2005. Ward Profiles: Facts and Figures about the Wards in the Kathmandu Metropolitan City. KMC, Kathmandu, Nepal.

KMC, World Bank, 2001. City Development Strategy and City Assistance Programme. KMC, Kathmandu, Nepal.

Khanal, R.K., 1993. Solid Waste Management in Kathmandu Valley, Nepal - Optimization of the Transportation System. Unpublished ME Thesis, Asian Institute of Technology, Bangkok, Thailand.

Manandhar, R., June 1, 2005. Basic Fact Sheet of Solid Waste Management of Kathmandu Municipal Corporation Unpublished record received electronically from KMC. 
Manandhar, R., August 30-September 1, 2006. Solid waste management of KMC. In: 3R South Asia Expert Workshop. Institute for Global Environmental Strategies, Kanagawa, Japan.

Marquez, M.Y., Ojeda, S., Hidalgo, H., 2008. Identification of behavior patterns in household solid waste generation in Mexicali's city: study case. Resources, Conservation and Recycling 52, 1299-1306.

Nightingale, D., Donnette, R., 2002. Household hazardous wastes. In: Tchobanoglous, G., Kreith, F. (Eds.), Handbook of Solid Waste Management, second ed. McGraw-Hill, New York, USA, pp. 10.1-10.36.

Nippon Koei Co. Ltd., Yachiyo Engineering Co. Ltd., 2004. The Study on the Solid Waste Management for the Kathmandu Valley, Interim Report (1). JICA, Kathmandu, Nepal.

Nippon Koei Co. Ltd., Yachiyo Engineering Co. Ltd., 2005. The Study on the Solid Waste Management for the Kathmandu Valley, Final Report: Main Report (Draft). JICA, Kathmandu, Nepal.

Ojeda-Benitez, S., Vega, C.A., Marquez-Montenegro, M.Y., 2008. Household solid waste characterization by family socioeconomic profile as unit of analysis. Resources, Conservation and Recycling 52, 992-999.

Philippe, F., Culot, M., 2009. Household solid waste generation and characteristics in Cape Haitian city, Republic of Haiti. Resources, Conservation and Recycling 54, $73-78$.

Pradhan, B., 2002. Study on a Current Status of Solid Waste Management in the Kathmandu Valley - A Solution. Unpublished MSc Thesis, School of Environmental Management and Sustainable Development, Kathmandu, Nepal.

Pradhan, P.K., 2004. Population growth, migration and urbanisation: environmenta consequences in Kathmandu Valley, Nepal. In: Unruh, J.D., Krol, M.S., Kliot, N. (Eds.), Environmental Change and Its Implications for Population Migration. Kluwer Academic Publishers, Dordrecht, the Netherlands, pp. 177-199.

Qu, X., Li, Z., Xie, X., Sui, Y., Yang, L., Chen, Y., 2009. Survey of composition and generation rate of household wastes in Beijing, China. Waste Management 29, 2618-2624.

Saeed, M.O., Hassan, M.N., Mujeebu, M.A., 2009. Assessment of municipal solid waste generation and recyclable materials potential in Kuala Lumpur, Malaysia. Waste Management 29, 2209-2213.

Scheaffer, R.L., Mendenhall III, W., Ott, R.L., 2006. Elementary Survey Sampling. Thompson Higher Education, Belmont, USA.
Sharholy, M., Ahmad, K., Mahmood, G., Trivedi, R.C., 2008. Municipal solid waste management in Indian cities - a review. Waste Management 28, 459-467.

Sharma, M., McBean, E., 2007. A methodology for solid waste characterization based on diminishing marginal returns. Waste Management 27, 337-344.

Sharma, P., 1989. Urbanization in Nepal. East-West Population Institute, Honolulu, HI, USA.

Solid Waste Management and Resource Mobilization Center (SWMRMC), Clean Energy Nepal, Environment and Public Health Organization, 2004. Solid Waste Management in Kathmandu Metropolitan City. HMG Nepal, Kathmandu, Nepal.

Sujauddin, M., Huda, S.M.S., Rafiqul Hoque, A.T.M., 2008. Household solid waste characteristics and management in Chittagong, Bangladesh. Waste Management 28, 1688-1695.

Tabasaran, O., 1976. Experts Report on the Reorganization of Solid Waste Disposal in the Kathmandu Valley Especially in the Cities of Kathmandu, Patan and Bhaktapur. GTZ, Stuttgart, Germany.

Tchobanoglous, G., 2002. Other special wastes: part 11D construction and demolition debris. In: Tchobanoglous, G., Kreith, F. (Eds.), Handbook of Solid Waste Management, second ed. McGraw-Hill, New York, USA, pp. 11.39-11.60.

Tchobanoglous, G., Theisen, H., Vigil, S., 1993. Integrated Solid Waste Management. McGraw-Hill, New York, USA.

Thakali, B., Karki, A.B., July 8, 2010. Personal Communication.

Thapa, G.B., 1998. Lessons learned from solid waste management in Kathmandu, Nepal. Habitat International 22 (2), 97-114.

Thapa, R.B., Murayama, Y., October 4-5, 2006. Land use change analysis using remote sensing and GIS: a case study of Kathmandu Metropolitan, Nepal. In: Proceedings of the 9th Annual Symposium of Center for Spatial Information Science. The University of Tokyo, Tokyo, Japan.

Troschinetz, A.M., Mihelcic, J.R., 2009. Sustainable recycling of municipal solid waste in developing countries. Waste Management 29, 915-923.

United Nations Environment Programme (UNEP), MOPE, SACEP, ICIMOD, NORAD, 2001. State of the Environment Nepal 2001. UNEP, Bangkok, Thailand.

Vesilind, P.A., Worrell, W., Reinhart, D., 2002. Solid Waste Engineering. Books/Cole Thomson Learning, Pacific Grove, CA, USA 